\title{
Bee food: the chemistry and nutritional value of nectar, pollen and mixtures of the two
}

\author{
Susan W. Nicolson ${ }^{*, \neq}$ \\ Department of Zoology and Entomology, University of Pretoria, Pretoria, 0002 South Africa \\ Received 28 June 2011. Accepted 28 June 2011
}

\begin{abstract}
Bees are herbivorous insects, consuming nectar and pollen throughout their life cycles. This paper is a brief review of the chemistry of these two floral resources and the implications for bee nutrition. Nectar is primarily an energy source, but in addition to sugars contains various minor constituents that may, directly or indirectly, have nutritional significance. Pollen provides bees with the protein, lipids, vitamins and minerals that are essential for larval rearing. Chemical analyses of pollen have tended to focus on the protein component of bee-collected pollens as an index of nutritional quality. However, the substantial nectar content of such samples ( $\sim 50 \%$ dry mass) should not be ignored, especially in view of current interest in measuring the nutritional quality of floral resources for bees.
\end{abstract}

Key words: bee forage, bee provisions, nectar sugars, protein, amino acids.

\section{INTRODUCTION}

Honeybees, and insect pollinators in general, are currently the focus of much scientific and media attention, owing to dramatic declines in their populations in some parts of the world, while at the same time demand is increasing for managed honeybees in agriculture (UNEP 2010). The multiple factors that may be contributing to pollinator declines include habitat fragmentation and loss, pathogens and parasites, and the use of pesticides. Interactions between these various factors are likely: for example, nutritional stress, due to a lack of floral resources or their poor quality, may lower the tolerance of bees to pesticides and diseases (Wahl \& Ulm 1983; Alaux et al. 2010).

Nectar is the main source of energy for bees, while pollen provides proteins, lipids, vitamins and minerals for brood rearing and development. Bees, social and solitary, differ from other insects in feeding on nectar and pollen, gathered by adult females, throughout development. Oil-collecting bees use floral oil instead of nectar in their larval provisions (Steiner \& Whitehead 1990) but are relatively few and will not be considered further here. In honeybees pollen consumption is highest in young adults, enabling their hypopharyngeal glands to produce jelly for feeding larvae, then after the transition to foraging at two weeks they consume mainly carbohydrate (Vasquez \& Olofsson 2009; Brodschneider \& Crailsheim 2010). In contrast, foraging workers eat little or no pollen,

${ }^{\ddagger}$ ZSSA Gold Medal winner for 2011.

*E-mail: swnicolson@zoology.up.ac.za suggesting they have reduced requirements for protein, although they have been shown to need proline for in-flight metabolism (Micheu et al. 2000). While the pollen requirements for reproduction of solitary bees can be substantial (Müller et al. 2006), it is easier to estimate the floral resources harvested by the tens of thousands in honeybee colonies. A single wild honeybee colony, for example, will harvest $120 \mathrm{~kg}$ of nectar and $20 \mathrm{~kg}$ of pollen annually in a temperate region (Seeley 1995); these amounts can be greatly exceeded in managed colonies. The need for protein during brood rearing is dramatically illustrated by the cannibalism of younger honeybee larvae that is induced by experimental pollen shortages in the colony (Schmickl \& Crailsheim 2001).

This paper is a brief review of the chemistry of these floral resources, with an emphasis on South African bee forage plants, and the nutritional implications for bees. Attention is drawn to the differences in composition between hand-collected and bee-collected pollens, because honeybees, directly and indirectly, begin altering pollen composition right from the first contact.

\section{NECTAR}

The energy content of a flower's nectar depends on its volume and sugar concentration (Corbet 2003). These nectar attributes, as well as the predominant sugar types, are often included in the floral features used to characterize pollination syndromes. However, many flower visitors are not predicted by floral syndromes: an example is the winter-flowering South African bee plant Aloe 
greatheadii var. davyana, which has the long tubular flowers and copious dilute nectar of bird-pollinated plants, yet is pollinated by honeybees and not birds (Human \& Nicolson 2008; Symes et al. 2009).

\section{Sugars}

Bees can discriminate between small differences in nectar concentration and prefer high concentrations (Roubik \& Buchmann 1984; Afik et al. 2006; Nicolson 2007c). Among social bees, the thoracic temperature of foragers is positively correlated with the sugar concentration in feeders (Waddington 1990; Nieh \& Sánchez 2005; Nieh et al. 2006). However, the response of bees to the three common nectar sugars (sucrose, glucose and fructose) is less clear (Afik et al. 2006, and references therein). Although honeybees prefer pure sucrose to pure glucose or fructose solutions, the latter are unlikely to occur in floral nectars and mixtures are more appropriate in preference tests. In field situations, nectars rich in hexose sugars, such as those of sunflower, canola or Eucalyptus species, are highly attractive to bees (Neff \& Simpson 1990; Nicolson 1994; Westcott \& Nelson 2001). Moreover, there is considerable evidence that nectar sugar composition may be determined by plant phylogeny rather than pollinator preferences (Nicolson 2007b). For example, flowers of the Lamiaceae, a major bee-pollinated family, are characterized by nectar rich in sucrose (Petanidou 2005). Regardless of the sugar composition, nectar sugars are easily digested by honeybee sucrases (Huber \& Mathison 1976). The absorption of monosaccharides has been assumed to be passive in bees (Crailsheim 1988), but recent research suggests that insects possess glucose transporters similar to those in mammals (Caccia et al. 2007).

While the vast majority of nectars is dominated by sucrose, glucose and fructose, the pentose sugar xylose is a major nectar sugar in Protea and Faurea, two sister genera of the Proteaceae (Nicolson \& van Wyk 1998). Both P. caffra and F. saligna are important honey sources in South Africa (Johannsmeier 2001), even though honeybees are unable to taste xylose and obtain no nutritional benefit from it (Allsopp et al. 1998).

Nectar is a good medium for microbial growth, and contamination with yeasts, easily transferred on the mouthparts of flower visitors such as bumblebees, can reduce the proportion of sucrose in nectar (Herrera et al. 2008); this is also seen in older flowers (Loper et al. 1976). Chemical analyses of nectar in relation to pollinator types and plant phylogeny should therefore be based on samples of freshly secreted nectar from unvisited flowers. In addition, other nectar components (see below) may confer some protection.

\section{Water}

The water content of nectar can vary greatly according to environmental conditions. Bees prefer to collect concentrated nectars, which maximize their energy gains (Roubik \& Buchmann 1984), but in arid conditions they may time their foraging to maximize water gains in nectar (Willmer \& Stone 1997). Dilute exposed nectars evaporate during the day and become more attractive: this applies to the nectar of Eucalyptus species (Nicolson 1994), which are major honey plants in South Africa and elsewhere. Alternatively, bees can deal with the excess water by evaporating it on the proboscis: honeybees collecting the dilute nectar of $A . g$. var. davyana $(20 \% \mathrm{w} / \mathrm{w})$ begin the conversion to honey on the return flight (Nicolson \& Human 2008). For the more usual situation of bees collecting concentrated nectars, the water content determines the viscosity and hence the upper limit for efficient licking by bees, which is around 60\% w/w sucrose (Roubik \& Buchmann 1984; Harder 1986).

\section{Other ingredients}

These are present in small amounts in nectar but can be important in terms of nutrition (and contribute to the taste of honey). In addition, these compounds may have indirect effects on nectar consumption of bees by influencing nectar palatability or microbial growth. Amino acids are the next most abundant nectar solutes after sugars, although occurring in low concentrations in insect-pollinated flowers (Gardener \& Gillman 2001). However, they are present in unexpectedly high concentrations in nectars of some southern African species of Erythrina and Aloe, although not in A. g. var. daryana (Nicolson 2007a). The literature on nectar amino acids is sparse, and although it has been suggested that pollen contamination might be responsible for some of the measured values, I was able to rule this out in nectar of A. marlothii. Proline in nectar has been claimed to attract honeybees (Carter et al. 2006); glycine is also attractive and improves the learning performance of bees (Kim \& Smith 2000). When we tested the responses of honeybees to added amino acids, using the proboscis extension reflex, proline, glycine and phenylalanine at concentrations of 
$2 \mathrm{mM}$ all elicited positive responses in $5 \% \mathrm{w} / \mathrm{w}$ sucrose (C.W.W. Pirk et al., unpubl. data). Proline is the most abundant amino acid in honey and its analysis is used in quality control (Hermosin et al. 2003): the high concentrations are derived from glandular secretions added during regurgitation as bees process the nectar into honey.

Little is known of inorganic ion concentrations in nectar (Nicolson 2007b), but high $\mathrm{K}^{+}$levels in onion and avocado nectar are thought to be unattractive to honeybees (Waller et al. 1972; Afik et al. 2006). Salts in nectar (and pollen) may be important in osmoregulation of bees (Nicolson 1990).

Secondary metabolites in nectar, such as alkaloids and phenolics, are paradoxical in view of the attractive function of nectar: however, they may serve to attract specialized pollinators or deter unwanted visitors (Adler 2000). Recently we have examined the responses of honeybees to nicotine as a model alkaloid, and found that deterrence depends on the nicotine concentration but also on the sugar concentration (A. Köhler et al., unpubl. data). Caffeine is present in Citrus nectar, which is highly attractive to bees (Kretschmar \& Baumann 1999). Phenolics in the nectar of A. vryheidensis deter honeybees (Johnson et al. 2006), but the lower phenolic levels in nectars of other Aloe species are less deterrent (S. Johnson, pers. comm.). In other studies phenolics have been reported as attractive to bees (Hagler \& Buchmann 1993; Afik et al. 2006; Liu et al. 2007). Some nectar toxins are not detected by bees, such as amygdalin in almond nectar, but postingestive effects contribute to avoidance learning (London-Shafir et al. 2003; Wright et al. 2010). One possible benefit of these secondary metabolites in nectar may be antibiotic activity against microbes (Adler 2000), a function that is shared by proteins in nectar, termed nectarins (Thornburg et al. 2003).

\section{POLLEN}

Most chemical analyses of pollen consist of protein determinations on bee-collected pollen obtained from pollen traps (for entomophilous plants, this is much easier than collecting fresh pollen). When honeybees pack pollen into their corbiculae, the addition of nectar enables them to transport pollen grains varying in size and surface texture (Thorp 1979). More nectar and glandular secretions are added in the hive, and microbial inoculation leads to fermentation during storage, forming bee bread which has higher nutritive value than bee-collected pollen (Herbert \& Shimanuki 1978;
Vasquez \& Olofsson 2009; Brodschneider \& Crailsheim 2010). Lactic acid bacteria are already present in bee-collected pollen, and may be a source of vitamins (Vasquez \& Olofsson 2009). The nutritional chemistry of hand-collected, beecollected and stored pollen has been compared for two important South African bee plants: $A$. $g$. var. davyana (Human \& Nicolson 2006) and sunflower Helianthus annuus (S.W. Nicolson \& H. Human, unpubl. data).

\section{Protein}

Protein levels in pollen vary widely, from 2-60\% dry mass in the hand-collected pollens of 377 species analysed by Roulston et al. (2000). Interestingly, these authors found no evidence that pollen protein concentration is higher in bee-pollinated species, but did demonstrate a relationship with plant phylogeny. Hand-collected pollen of $A$. $g$. var. dayyana has a high protein concentration of $51 \%$ dry mass, but this is diluted to $31 \%$ during collection by honeybees and to $28 \%$ in bee bread (Human \& Nicolson 2006). Sunflower pollen is considered to be of poor quality for bees because of its low protein content of 13-15\% after collection by bees (Pernal \& Currie 2000; Somerville \& Nicol 2006; S.W. Nicolson \& H. Human, unpubl. data). There is little evidence that bees can assess pollen quality and choose pollens with high protein levels (Pernal \& Currie 2001; Roulston \& Cane 2002). However, manipulation of the protein content of pollen provided to bumblebee colonies led to a small but significant increase in thoracic temperatures of bees collecting higher quality pollen (Mapalad et al. 2008). Cook et al. (2003) showed that bees provided with two pollens chose the one that was richer in some essential amino acids, but other factors may have been involved and more studies are needed. Pollen substitutes developed for the supplementary feeding of honeybee colonies are based on high protein levels (Brodschneider \& Crailsheim 2010). However, our study of protein and carbohydrate regulation in caged worker honeybees shows that high protein may not always be beneficial in the absence of larval rearing (Altaye et al. 2010); see also Roulston \& Cane (2002); Human et al. (2007).

Amino acid composition determines the amount of pollen required by bees, more than its protein content. The minimum amino acid requirements for honeybees were established by de Groot (1953); these can be compared with data on the amino acid composition of various pollens, usually 
Table 1. Proportions of pollen and nectar in bee provisions.

\begin{tabular}{|c|c|c|c|c|}
\hline Species & $\begin{array}{l}\text { Protein in hand- } \\
\text { collected pollen } \\
\text { (\% dry mass) }\end{array}$ & $\begin{array}{l}\text { Protein in bee } \\
\text { provisions* } \\
\text { (\% dry mass) }\end{array}$ & $\begin{array}{c}\text { Fraction of dry } \\
\text { mass that is pollen** }\end{array}$ & Reference \\
\hline Virgilia divaricata & $25.0 \pm 2.0$ & $15.9 \pm 0.9$ & 0.64 & Louw \& Nicolson 1983 \\
\hline $\begin{array}{l}\text { Aloe greatheadii var. } \\
\text { davyana }\end{array}$ & $50.8 \pm 2.7$ & $28.1 \pm 1.6$ & 0.55 & Human \& Nicolson 2006 \\
\hline Helianthus annuus & $26.5 \pm 0.6$ & $13.3 \pm 0.1$ & 0.50 & Nicolson \& Human, unpubl. \\
\hline
\end{tabular}

Protein concentrations given as means \pm S.E. $(n=6)$

*Brood provisions of carpenter bees (Xylocopa capitata) foraging on Virgilia divaricata or stored pollen collected by Apis mellifera scutellata from aloes or sunflowers.

${ }^{* *}$ Assumes no protein contributed by nectar.

bee-collected pollens in which a nectar or glandular origin of amino acids cannot be ruled out (Loper \& Cohen 1987; Cook et al. 2003; Human \& Nicolson 2006; Somerville \& Nicol 2006). Bee-collected pollens of Eucalyptus species have a protein concentration of $24.9 \pm 0.6 \%$ dry mass (mean \pm S.E., $n=19$ species), but are generally deficient in isoleucine (Somerville \& Nicol 2006), suggesting that bees will not do well on an exclusive diet of Eucalyptus pollen. Poor brood rearing in bees fed dandelion pollen may be due to inadequate levels of several amino acids (Loper \& Cohen 1987).

\section{Carbohydrate (and the mixture problem)}

In stored aloe and sunflower pollen, the added nectar and secretions cause other nutrients such as protein to be diluted by $\sim 50 \%$ (Table 1 ). The added nectar will mainly affect the carbohydrate component of the brood food, but possibly other components too, for example if amino acid levels are high in the nectar being collected. The data on pollen composition reported by Todd \& Bretherick (1942) included a single species, Pinus contorta, represented in both hand-collected and bee-collected samples: the percentage of sugars increased by $34 \%$ in bee-collected pollen.

It is seldom acknowledged that nectar sugars can be a substantial component of pollen pellets. A notable exception is the extensive data set on pollen protein concentrations of Roulston et al. (2000) which is based on hand-collected pollen. For nine plant species, these authors compared protein concentrations in hand-collected and bee-collected pollens, and found a pollen fraction of 0.57 of the total mass (range 0.38-0.83): although the samples of hand-collected and bee-collected pollens were not collected at the same time (T. Roulston, pers. comm.). Similar protein concentrations have been reported in hand-collected and bee-collected almond pollen, but the former was obtained by sifting shredded anthers through copper mesh (Loper et al. 1980; Standifer et al. 1980), and may have been contaminated with anther tissue which would be low in protein; see higher values for hand-collected pollen of other Prunus species in Roulston et al. (2000). Some researchers have washed bee-collected pollens to remove the sugars and enable comparison with hand-collected pollens (Müller et al. 2006, Hanley et al. 2008); this method is suitable for counting pollen grains but not for chemical analyses, because it risks the loss of other components and has not been tested against hand collected pollen. Scott et al. (1993) used ethanol extraction to separate the sugars from carpenter bee provisions, and found a sugar content of 4-69\% dry mass.

Starch is absent from stored pollen, no doubt due to enzymatic action (Herbert \& Shimanuki 1978). Fibre is not commonly analysed in pollen but makes up 7\% dry mass in hand-collected Virgilia pollen (Louw \& Nicolson 1983) and 7\% on average in the bee-collected samples of unknown floral origin analysed by Herbert \& Shimanuki (1978). Fibre may represent a higher proportion of total mass in small pollen grains. Because a high proportion of pollen-derived carbohydrate may be indigestible, the added nectar sugars are nutritionally important to bees.

\section{Other ingredients}

Total lipid content is usually less than $10 \%$ dry mass. Low lipid levels (0.6-1.9\% dry mass) are found in bee-collected pollen of eucalypts (Bell et al. 1983; Manning \& Harvey 2002), whereas an extraordinary value of $32 \%$ dry mass is given for canola pollen by (Evans et al. 1987). Higher levels of lipid are considered attractive to bees (Singh et al. 1999). 
Fatty acid composition is known for some pollens, and may be nutritionally important (Manning 2001). Some fatty acids show antibiotic activity against the causative agent of American foulbrood disease (Feldlaufer et al. 1993). Pollenkitt, the sticky coating on entomophilous pollens, contains fatty acids, and volatile components may be chemical cues for pollinators (Dobson 1988) rather than of nutritional value. Sterols in pollen are essential for bees (Brodschneider \& Crailsheim 2010).

As in the case of nectar, it is not clear whether secondary metabolites are present because of defensive roles in the rest of the plant. High concentrations of nicotine and amygdalin have been measured in hand-collected pollen of tobacco and bee-collected pollen of almond, respectively (Detzel \& Wink 1993, London-Shafir et al. 2003). For plants containing pyrrolizidine alkaloids, high values in pollen may lead to contamination of nectar and then honey (Boppré et al. 2005; Reinhard et al. 2009).

\section{CONCLUSION}

Pollen protein levels are frequently underestimated in the literature because the information is derived from bee-collected pollens containing an unknown amount of added nectar. Bee-collected pollen pellets of Echium plantagineum, an important introduced forage plant in Australia, contain $37.4 \%$ protein (Corbet \& Delfosse 1984; Somerville \& Nicol 2006) - does this reflect protein levels exceeding $70 \%$ dry mass in fresh pollen of this species, or do honeybees add less nectar to E. plantagineum pollen during collection? The extent of dilution with nectar sugars is not predictable: it may depend on the properties of the pollen or the concentration of nectars available to bees at the time (Roulston \& Cane 2000).

The availability of pollen nutrients to consumers depends on how easily the pollen can be digested, and it is possible that added sugars may enhance this process. The pollen exine is generally considered the main barrier to digestion, but extensive extraction of pollen grain contents can take place through pores while the exine remains intact (Human \& Nicolson 2003; Human et al. 2007). Various possible methods used to digest pollen are detailed by Roulston \& Cane (2000), who point out the confusing data obtained from different plant and bee species. Studies comparing the digestion of fresh pollen and food provisions by bees would show whether the addition of nectar sugars aids digestion of pollen grains (Roulston \& Cane 2000). Pollen digestion is not a problem for honeybee larvae because of the transformation to proteinrich jelly in the hypopharyngeal glands of nurse bees. The relative proportions of pollen and nectar in bee provisions are thus of more direct relevance to the larvae of mass-provisioning species.

It is commonly assumed that bees visit more plant species for nectar than for pollen, and the concept of floral specialization in bees refers to pollen foraging. Cane \& Sipes (2006) discuss various methods used to determine pollen use by bees, and point out the need to consider widely differing pollen grain volumes when quantifying bee diets. Nectar sources, however, can be determined only by direct observation of foragers at flowers: the examination of pollen grains in honey is not a reliable method (Todd \& Vansell 1942). From an evolutionary viewpoint it makes sense for bees to be more discriminating in their choice of pollen sources: the pollen is needed on a shortterm basis for larval rearing, whereas the colony requires full honey stores to survive adverse conditions. Diversity in bee diets may be necessary to avoid nutritional deficiencies (Schmidt et al. 1995) and to dilute toxins, but need not involve many plant species. Honeybee colonies sampled at various sites in Israel over a year usually collected pollen from 5-9 species at a time (Avni et al. 2009). Similar dependence on a few pollen sources was noted by Keller et al. (2005), based mainly on Swiss studies, and mixed pollens from five plant species were found to be better than single pollens for maintaining honeybee immune systems (Alaux et al. 2010). More data on the amino acid composition of fresh pollens are needed to assess the nutritional significance of these pollen choices at the colony level: are they due to floral constancy or the selection of complementary pollens to compensate for amino acid imbalances?

\section{ACKNOWLEDGEMENTS}

I thank Christian Pirk, Jeri Wright, Sharoni Shafir and T'ai Roulston for helpful comments.

\section{REFERENCES}

ADLER, L.S. 2000. The ecological significance of toxic nectar. Oikos 91: 409-420.

AFIK, O., DAG, A., KEREM, Z. \& SHAFIR, S. 2006. Analyses of avocado (Persea americana) nectar properties and their perception by honey bees (Apis mellifera). Journal of Chemical Ecology 32: 1949-1963.

ALAUX, C., DUCLOZ, F., CRAUSER, D. \& LE CONTE, Y. 2010. Diet effects on honeybee immunocompetence. Biology Letters 6: 562-565. 
ALLSOPP, M.H., NICOLSON, S.W. \& JACKSON, S. 1998. Xylose as a nectar sugar: the response of Cape honeybees, Apis mellifera capensis Eschscholtz (Hymenoptera: Apidae). African Entomology 6: 317-323.

ALTAYE, S.Z., PIRK, C.W.W., CREWE, R.M. \& NICOLSON, S.W. 2010. Convergence of carbohydrate-biased intake targets in caged worker honeybees fed different protein sources. Journal of Experimental Biology 213: 3311-3318.

AVNI, D., DAG, A. \& SHAFIR, S. 2009. Pollen sources for honeybees in Israel: source, periods of shortage, and influence on population growth. Israel Journal of Plant Sciences 57: 263-275.

BELL, R.R., THORNBER, E.J., SEET, J.L.L., GROVES, M.T., HO, N.P. \& BELL, D.T. 1983. Composition and protein quality of honeybee-collected pollen of Eucalyptus marginata and Eucalyptus calophylla. Journal of Nutrition 113: 2479-2484.

BOPPRÉ, M., COLEGATE, S.M. \& EDGAR, J.A. 2005. Pyrrolizidine alakoids of Echium vulgare honey found in pure pollen. Journal of Agricultural and Food Chemistry 53: 594-600.

BRODSCHNEIDER, R. \& CRAILSHEIM, K. 2010. Nutrition and health in honey bees. Apidologie 41: 278-294.

CACCIA, S., CASARTELLI, M., GRIMALDI, A., LOSA, E., DE EGUILEOR, M., PENNACCHIO, F. \& GIORDANA, B. 2007. Unexpected similarity of intestinal sugar absorption by SGLT1 and apical GLUT2 in an insect (Aphidius ervi, Hymenoptera) and mammals. American Journal of Physiology - Regulatory, Integrative and Comparative Physiology 292: R2284R2291.

CANE, J.H. \& SIPES, S. 2006. Characterizing floral specialization by bees: analytical methods and a revised lexicon for oligolecty. In: Plant-Pollinator Interactions: from Specialization to Generalization, (eds) N.M. Waser \& J. Ollerton, pp. 99-122. University of Chicago Press, Chicago.

CARTER, C., SHAFIR, S., YEHONATAN, L., PALMER, R. G. \& THORNBURG, R. 2006. A novel role for proline in plant floral nectars. Naturwissenschaften 93: 72-79.

COOK, S.M., AWMACK, C.S., MURRAY, D.A. \& WILLIAMS, I.H. 2003. Are honey bees' foraging preferences affected by pollen amino acid composition? Ecological Entomology 28: 622-627.

CORBET, S.A. 2003. Nectar sugar content: estimating standing crop and secretion rate in the field. Apidologie 34: 1-10.

CORBET, S.A. \& DELFOSSE, E.S. 1984. Honeybees and the nectar of Echium plantagineum L. in south-eastern Australia. Australian Journal of Ecology 9: 125-139.

CRAILSHEIM, K. 1988. Intestinal transport of sugars in the honeybee (Apis mellifera L.). Journal of Insect Physiology 34: 839-845.

DE GROOT, A.P. 1953. Protein and amino acid requirements of the honey bee. Physiologia Comparata Oecologia 3: 1-83.

DETZEL, A. \& WINK, M. 1993. Attraction, deterrence or intoxication of bees (Apis mellifera) by plant allelochemicals. Chemoecology 4: 8-18.

DOBSON, H.E.M. 1988. Survey of pollen and pollenkitt lipids - chemical cues to flower visitors? American Journal of Botany 75: 170-182.
EVANS, D.E., ROTHNIE, N.E., PALMER, M.V., BURKE, D.G., SANG, J.P., KNOX, R.B., WILLIAMS, E.G., HILLIARD, E.P. \& SALISBURY, P.A. 1987. Comparative analysis of fatty acids in pollen and seed of rapeseed. Phytochemistry 26: 1895-1897.

FELDLAUFER, M.F., KNOX, D.A., LUSBY, W.R. \& SHIMANUKI, H. 1993. Antimicrobial activity of fatty acids against Bacillus larvae, the causative agent of American foulbrood disease. Apidologie 24: 95-99.

GARDENER, M.C. \& GILLMAN, M.P. 2001. Analyzing variability in nectar amino acids: composition is less variable than concentration. Journal of Chemical Ecology 27: 2545-2558.

HAGLER, J.R. \& BUCHMANN, S.L. 1993. Honey bee (Hymenoptera: Apidae) foraging responses to phenolic-rich nectars. Journal of the Kansas Entomological Society 66: 223-230.

HANLEY, M.E., FRANCO, M., PICHON, S., DARVILL, B. \& GOULSON, D. 2008. Breeding system, pollinator choice and variation in pollen quality in British herbaceous plants. Functional Ecology 22: 592-598.

HARDER, L.D. 1986. Effects of nectar concentration and flower depth on flower handling efficiency of bumble bees. Oecologia 69: 309-315.

HERBERT, E.W. \& SHIMANUKI, H. 1978. Chemical composition and nutritive value of bee-collected and bee-stored pollen. Apidologie 9: 33-40.

HERMOSÍN. I., CHICÓN, R.M. \& CABEZUDO, M.D. 2003. Free amino acid composition and botanical origin of honey. Food Chemistry 83: 263-268.

HERRERA, C.M., GARCÍA, I.M. \& PÉREZ, R. 2008. Invisible floral larcenies: microbial communities degrade floral nectar of bumble bee-pollinated plants. Ecology 89: 2369-2376.

HUBER, R.E. \& MATHISON, R.D. 1976. Physical, chemical, and enzymatic studies on the major sucrase of honey bees (Apis mellifera). Canadian Journal of Biochemistry 54: 153-164.

HUMAN, H. \& NICOLSON, S.W. 2003. Digestion of maize and sunflower pollen by the spotted maize beetle Astylus atromaculatus (Melyridae): is there a role for osmotic shock? Journal of Insect Physiology, 49: 633-643.

HUMAN, H. \& NICOLSON, S.W. 2006. Nutritional content of fresh, bee-collected and stored pollen of Aloe greatheadii var. davyana (Asphodelaceae). Phytochemistry 67: 1486-1492.

HUMAN, H. \& NICOLSON, S.W. 2008. Flower structure and nectar availability in Aloe greatheadii var. davyana: an evaluation of a winter nectar source for honeybees. International Journal of Plant Science 169: 263-269.

HUMAN, H., NICOLSON, S.W., STRAUSS, K., PIRK, C.W.W. \& DIETEMANN, V. 2007. Influence of pollen quality on ovarian development in honeybees (Apis mellifera scutellata). Journal of Insect Physiology 53: 649-655.

JOHANNSMEIER, M.F. (ed.) 2001. Beekeeping in South Africa, 3rd edition. Plant Protection Research Institute, Agricultural Research Council of South Africa, Pretoria.

JOHNSON, S.D., HARGREAVES, A.L. \& BROWN, M. 2006. Dark bitter-tasting nectar functions as a filter of flower visitors in a bird-pollinated plant. Ecology 87: 2709-2716. 
KELLER, I., FLURI, P. \& IMDORF, A. 2005. Pollen nutrition and colony development in honey bees: Part I. Bee World 86: 3-10.

KIM, Y.S. \& SMITH, B.H. 2000. Effect of an amino acid on feeding preferences and learning behavior in the honey bee, Apis mellifera. Journal of Insect Physiology 46: 793-801.

KRETSCHMAR, J.A. \& BAUMANN, T.W. 1999. Caffeine in Citrus flowers. Phytochemistry 52: 19-23.

LIU, F., CHEN, J., CHAI, J., ZHANG, X., BAI, X., HE, D. \& ROUBIK, D.W. 2007. Adaptive functions of defensive plant phenolics and a non-linear bee response to nectar components. Functional Ecology 21: 96-100.

LONDON-SHAFIR, I., SHAFIR, S. \& EISIKOWITCH, D. 2003. Amygdalin in almond nectar and pollen - facts and possible roles. Plant Systematics and Evolution 238: 87-95.

LOPER, G.M. \& COHEN, A.C. 1987. Amino acid content of dandelion pollen, a honey bee (Hymenoptera: Apidae) nutritional evaluation. Journal of Economic Entomology 80: 14-17.

LOPER, G.M., STANDIFER, L.N., THOMPSON, M.J. \& GILLIAM, M. 1980. Biochemistry and microbiology of bee-collected almond (Prunus dulcis) pollen and bee bread. I. Fatty acids, sterols, vitamins and minerals. Apidologie 11: 63-73.

LOPER, G.M., WALLER, G.D. \& BERDEL, R.L. 1976. Effect of flower age on sucrose content in nectar of citrus. HortScience 11: 416-417.

LOUW, G.N. \& NICOLSON, S.W. 1983. Thermal, energetic and nutritional considerations in foraging and reproduction of the carpenter bee Xylocopa capitata. Journal of the Entomological Society of South Africa 46: 227-240.

MANNING, R. 2001. Fatty acids in pollen: a review of their importance for honey bees. Bee World 82: 60-75.

MANNING, R. \& HARVEY, M. 2002. Fatty acids in honeybee-collected pollens from six endemic Western Australian eucalypts and the possible significance to the Western Australian beekeeping industry. Australian Journal of Experimental Agriculture 42: 217-223.

MAPALAD, K.S., LEU, D. \& NIEH, J.C. 2008. Bumble bees heat up for high quality pollen. Journal of Experimental Biology 211: 2239-2242.

MICHEU, S., CRAILSHEIM, K. \& LEONHARD, B. 2000. Importance of proline \& other amino acids during honeybee flight - Apis mellifera carnica Pollmann. Amino Acids 18: 157-175.

MÜLLER, A., DIENER, S., SCHNYDER, S., STUTZ, K., SEDIVY, C. \& DORN, S. 2006. Quantitative pollen requirements of solitary bees: implications for bee conservation \& the evolution of bee-flower relationships. Biological Conservation,130: 604-615.

NEFF, J.L. \& SIMPSON, B.B. 1990. The roles of phenology \& reward structure in the pollination biology of wild sunflower (Helianthus annuus L., Asteraceae). Israel Journal of Botany 39: 197-216.

NICOLSON, S.W. 1990. Osmoregulation in a nectarfeeding insect, the carpenter bee Xylocopa capitata: water excess and ion conservation. Physiological Entomology 15: 433-440.

NICOLSON, S.W. 1994. Eucalyptus nectar: production, availability, composition and osmotic consequences for the larva of the eucalypt nectar fly, Drosophila flavohirta. South African Journal of Science 90: 75-79.

NICOLSON, S.W. 2007a. Amino acid concentrations in the nectars of southern African bird-pollinated flowers, especially Aloe and Erythrina. Journal of Chemical Ecology 33: 1707-1720.

NICOLSON, S.W. 2007b. Nectar chemistry. In: Nectaries and Nectar, (eds) S.W. Nicolson, M. Nepi \& E. Pacini, pp. 215-264. Springer, Dordrecht.

NICOLSON, S.W. 2007c. Nectar consumers. In: Nectaries and Nectar, (eds) S.W. Nicolson, M. Nepi \& E. Pacini, pp. 289-342. Springer, Dordrecht.

NICOLSON, S.W. \& HUMAN, H. 2008. Bees get a head start on honey production. Biology Letters 4: 299-301.

NICOLSON, S.W. \& VAN WYK, B-E. 1998. Nectar sugars in Proteaceae: patterns and processes. Australian Journal of Botany 46: 489-504.

NIEH, J.C., LEÓN, A., CAMERON, S. \& VANDAME, R. 2006. Hot bumble bees at good food: thoracic temperature of feeding Bombus wilmattae foragers is tuned to sugar concentration. Journal of Experimental Biology 209: 4185-4192.

NIEH, J. C. \& SÁNCHEZ, D. 2005. Effect of food quality, distance and height on thoracic temperature in the stingless bee Melipona panamica. Journal of Experimental Biology 208: 3933-3943.

PERNAL, S.F. \& CURRIE, R.W. 2000. Pollen quality of fresh and 1-year-old single pollen diets for worker honey bees (Apis mellifera L.). Apidologie 31: 387-409.

PERNAL, S.F. \& CURRIE, R.W. 2001. The influence of pollen quality on foraging behavior in honeybees (Apis mellifera L.). Behavioral Ecology and Sociobiology 51: 53-68.

PETANIDOU, T. 2005. Sugars in Mediterranean floral nectars: an ecological and evolutionary approach. Journal of Chemical Ecology 31: 1065-1088.

REINHARD, A., JANKE, M., VON DER OHE, W., KEMPF, M., THEURING, C., HARTMANN, T., SCHREIER, P. \& BEUERLE, T. 2009. Feeding deterrence and detrimental effects of pyrrolizidine alkaloids fed to honey bees (Apis mellifera). Journal of Chemical Ecology 35: 1086-1095.

ROUBIK, D.W. \& BUCHMANN, S.L. 1984. Nectar selection by Melipona and Apis mellifera (Hymenoptera: Apidae) and the ecology of nectar intake by bee colonies in a tropical forest. Oecologia 61: 1-10.

ROULSTON, T.H. \& CANE, J.H. 2000. Pollen nutritional content and digestibility for animals. Plant Systematics and Evolution 222: 187-209.

ROULSTON, T.H. \& CANE, J.H. 2002. The effect of pollen protein concentration on body size in the sweat bee Lasioglossum zephyrum (Hymenoptera: Apiformes). Evolutionary Ecology 16: 49-65.

ROULSTON, T.H., CANE, J.H. \& BUCHMANN, S.L. 2000. What governs protein content of pollen: pollinator preferences, pollen-pistil interactions, or phylogeny? Ecological Monographs 70: 617-643.

SCHMICKL, T. \& CRAILSHEIM, K. 2001. Cannibalism and early capping: strategy of honeybee colonies in times of experimental pollen shortages. Journal of Comparative Physiology A, 187: 541-547.

SCHMIDT, L.S., SCHMIDT, J.O., RAO, H., WANG, W. \& XU, L. 1995. Feeding preference and survival of young worker honey bees (Hymenoptera: Apidae) fed rape, sesame, and sunflower pollen. Journal of 
Economic Entomology 88: 1591-1595.

SCOTT, P.E., BUCHMANN, S.L. \& O'ROURKE, M.K. 1993. Evidence for mutualism between a flowerpiercing carpenter bee and ocotillo: use of pollen and nectar by nesting bees. Ecological Entomology 18: 234-240.

SEELEY, T.D. 1995. The Wisdom of the Hive: the Social Physiology of Honey Bee Colonies. Harvard University Press, Cambridge, Mass.

SINGH, S., SAINI, K. \& JAIN, K.L. 1999. Quantitative comparison of lipids in some pollens and their phagostimulatory effects in honey bees. Journal of Apicultural Research 38: 87-92.

SOMERVILLE, D.C. \& NICOL, H.I. 2006. Crude protein and amino acid composition of honey bee-collected pollen pellets from south-east Australia and a note on laboratory disparity. Australian Journal of Experimental Agriculture 46: 141-149.

STANDIFER, L.N., McCAUGHEY, W.F., DIXON, S.E., GILLIAM, M. \& LOPER, G.M. 1980. Biochemistry and microbiology of pollen collected by honey bees (Apis mellifera L.) from almond, Prunus dulcis. II. Protein, amino acids and enzymes. Apidologie 11: 163-171.

STEINER, K.E. \& WHITEHEAD, V.B. 1990. Pollinator adaptation to oil-secreting flowers Rediviva and Diascia. Evolution 44: 1701-1707.

SYMES, C.T., HUMAN, H. \& NICOLSON, S.W. 2009. Appearances can be deceiving: pollination in two sympatric winter-flowering Aloe species. South African Journal of Botany 75: 668-674.

THORNBURG, R.W., CARTER, C., POWELL, A., MITTLER, R., RIZHSKY, L. \& HORNER, H.T. 2003. A major function of the tobacco floral nectary is defense against microbial attack. Plant Systematics and Evolution 238: 211-218.

THORP, R.W. 1979. Structural, behavioral, and physio- logical adaptations of bees (Apoidea) for collecting pollen. Annals of the Missouri Botanical Garden 66: 788-812.

TODD, F.E. \& BRETHERICK, O. 1942. The composition of pollens. Journal of Economic Entomology 35: 312-317.

TODD, F. E. \& VANSELL, G.H. 1942. Pollen grains in nectar and honey. Journal of Economic Entomology 35: 728-731.

UNEP 2010. UNEP Emerging Issues: Global Honey Bee Colony Disorder and other Threats to Insect Pollinators. United Nations Environment Programme.

VÁSQUEZ, A. \& OLOFSSON, T.C. 2009. The lactic acid bacteria involved in the production of bee pollen and bee bread. Journal of Apicultural Research and Bee World 48: 189-195.

WADDINGTON, K.D. 1990. Foraging profits and thoracic temperature of honey bees (Apis mellifera). Journal of Comparative Physiology B 160: 325-329.

WAHL, O. \& ULM, K. 1983. Influence of pollen feeding and physiological condition on pesticide sensitivity of the honey bee Apis mellifera carnica. Oecologia 59: 106-128.

WALLER, G.D., CARPENTER, E.W. \& ZIEHL, O.A. 1972. Potassium in onion nectar and its probable effect on attractiveness of onion flowers to honey bees. Journal of the American Society for Horticultural Science 97: 535-539.

WESTCOTT, L. \& NELSON, D. 2001. Canola pollination: an update. Bee World 82: 115-129.

WILLMER, P. \& STONE, G. 1997. Temperature and water relations in desert bees. Journal of Thermal Biology 22: 453-465.

WRIGHT, G.A., MUSTARD, J.A., SIMCOCK, N.K., ROSS-TAYLOR, A.A.R., McNICHOLAS, L.D., POPESCU, A. \& MARION-POLL, F. 2010. Parallel reinforcement pathways for conditioned food aversions in the honeybee. Current Biology 20: 2234-2240.

Responsible Editor: J.H. van Wyk 